\title{
A Brief Ethnbotanical Survey of Some Medicinal Plants Used by the Kanjoo Community in Meru County, Kenya
}

\author{
Amulka $0^{1 *}$, Mulei JM² and Gatwiri BP ${ }^{3}$ \\ ${ }^{1}$ Department of Applied Plant Sciences, Maseno University, Kenya \\ ${ }^{2}$ Department of Biological Sciences, University of Eldoret, Kenya \\ ${ }^{3}$ Kibirichia, Kenya
}

Submission: June 15, 2017; Published: July 28, 2017

*Corresponding author: Amuka 0, Department of Applied Plant Sciences, Maseno University, Private Bag Maseno 40105, Kenya, Email: oamuka@maseno.ac.ke

\begin{abstract}
Medicinal plants in Kenya are not adequately documented despite their widespread use. The threat of complete disappearance of the knowledge on herbal medicine warrants an urgent need to document the information. An ethno botanical study on traditional use of medicinal plants was conducted between January and February 2015 in Kanjoo location Meru County. The study focused on identification of the plants, diseases treated, plant part used, preparation methods, administration route and other plant uses. Data collection involved semi-structured interviews with 30 purposively selected traditional healers. Twenty eight plant species distributed in 26 genera, 22 families and three different life forms were identified as being useful for treating 17 human aliments. Majority of the species were trees and shrubs; leaves were the most dominant plant part used; oral route of administration was commonest and hot water decoction most preferred method of preparation. Various non-medicinal uses of the plants were also recorded. The study reveals that the Kanjoo area is rich in medicinal plants and the knowledge on herbal medicine is still part of the cultural heritage in the community. Preservation of this knowledge is important and phytochemical analysis of the plants may provide some useful leads for the development of new drugs.
\end{abstract}

Keywords: Kanjoo; Meru; Herbal medicine; Traditional healers; Ethno botany

\section{Introduction}

Plants form an integral part of human life. They have been used from time immemorial by humans as medicines [1]. Ancient civilizations' in the world thrived on use of plants for their livelihood [2]. In the recent past to date medicinal plants have generated lots of interest [3-5]. Several compounds currently in use as drugs or templates for synthesis of allopathic drugs have been derived from plants such as Vincristine, Vinblastine, Emetine, Quinine, Morphine, Codeine, and Artemisinin among others. There is need for new drugs to manage emerging and re-emerging diseases [6]. Currently microorganisms have a tendency of developing resistance to antibiotics in the market [7-9]. Large population in the world (80\%) use traditional forms of treatment [10].

The Ameru are indigenous inhabitants in sub-Saharan Africa. They are Farmers and forest products users. The use of wild and cultivated plants in this part of Kenya is becoming increasingly visible in regard to medicine, food, material, social uses, construction and fuel. Although ethnobotanical studies have been conducted in many parts of Meru County [11,12] little has been done in the Kanjoo Community. Traditional practitioners are regularly consulted by the community as they have a rich indigenous knowledge base and are always available. There is limited documentation of the medicinal plants used by the Kanjoo people as well as their pharmacological and phytochemical properties. The fragile forest ecosystems are getting disseminated due to population pressure and accelerated reduction in the biodiversity in these areas. There is fear of loss of valuable information due to acculturation of the present generation. Ethnic cells in the African set-up in most may give a completely monolithic cultural distinction with gradual succession into the neighbors. The Meru is one such group which the Kanjoo may serve as a representative. The study was undertaken to explore the Ethno medicine of the Kanjoo people, specifically to 
A. Document some medicinal plants used in folklore medicine.

B. Identify the plants; part used, pharmacological profile and non-medicinal uses.

\section{Materials and Methods}

\section{Study area and data collection}

The study was conducted amongst Kanjoo Community in Meru County, Kenya, which is located at $0^{\circ} 07^{\prime} \mathrm{N}$ latitude and $37^{\circ} 43^{\prime}$ E longitude, about $80 \mathrm{~km}$ from Meru town, $1600 \mathrm{~m}$ above sea level. It has a population of about 9,806 people. The community live is next to the Meru national Reserve. They have a lot common with wildlife hence are used to live in harmony with nature. The area receives about $380-1000 \mathrm{~mm}$ rainfall in two seasons. Vegetation varies from typical tropical savanna to grassland interspersed with shrubs and small trees. The nature of the environment therefore accommodates a diverse variety of flora and fauna.

Ethno botanical data was collected between January and February 2015. Thirty traditional healers, 13 males and 17 females were purposefully sampled and interviewed using semi structured questionnaires. The study focused on plant identification, disease(s) treated, plant part used, methods of preparation, route of administration and other uses of the plant. The collected specimens were prepared following standard herbarium procedures and identified using various floras $[13,14]$. Descriptive statistics was used to analyze the data.

\section{Results and Discussion}

Twenty eight plant species distributed in 26 genera and 22 families and encompassing four different life forms were identified as being useful for treating 17 human aliments (Table 1). Most of the plants used in the area are well known and are indigenous to the area. The knowledge correlates with uses reported elsewhere, for example, the leaves of Ajuga integrifolia and Senna didymobotrya are used for the treatment of malaria in other parts of Kenya [15]. Furthermore, it confirms the fact that knowledge is uniformly spread rural societies. The dominant families of Ethnobotanical importance were: Asteraceae 4 species, Fabaceae 2 species and Lamiaceae 2 species. Other studies have recorded Asteraceae as being among the families with high number of medicinal species $[16,17]$.

Table1: Plant species based on traditional their reputation for use as medicine.

\begin{tabular}{|c|c|c|c|c|c|c|c|}
\hline Family & Species & Local Name & Habit & Part Used & $\begin{array}{l}\text { Disease } \\
\text { Treated }\end{array}$ & $\begin{array}{c}\text { Preparation/ } \\
\text { Administration } \\
\text { Route }\end{array}$ & $\begin{array}{c}\text { Preparation/ } \\
\text { Administration } \\
\text { Route }\end{array}$ \\
\hline $\begin{array}{c}\text { Amarathus } \\
\text { palmeri S. Wats. }\end{array}$ & $\begin{array}{c}\text { Amarathus palmeri } S . \\
\text { Wats. }\end{array}$ & Terere & Herb & $\mathrm{L}$ & Diarrhea & $\begin{array}{c}\text { Hot water } \\
\text { Decoction; Oral }\end{array}$ & $\begin{array}{l}\text { Leaves used as } \\
\text { vegetables }\end{array}$ \\
\hline Amaryvidaceae & Allium sativum $L$. & Kubuturu & Herb & $\mathrm{W} / \mathrm{P}$ & Ulcers & Infusion; Oral & Used as spice \\
\hline Apocynaceae & Apocynaceae & Kamuria & Shrub & $\mathrm{RB}$ & $\begin{array}{l}\text { Malaria, } \\
\text { relieves pain }\end{array}$ & $\begin{array}{c}\text { Hot water } \\
\text { decoction; Oral }\end{array}$ & Fruits edible \\
\hline \multirow{4}{*}{ Asteraceae } & Bidens pilosa L. & Muratha ngii & Herb & $\mathrm{W} / \mathrm{P}$ & Fresh wounds & $\begin{array}{c}\text { Crushing and } \\
\text { squeezing; Dermal }\end{array}$ & Fodder \\
\hline & $\begin{array}{c}\text { Sckhuriapinnata(Lam.) } \\
\text { O.Kunte. }\end{array}$ & Gakuinini & Herb & $\mathrm{W} / \mathrm{P}$ & $\begin{array}{l}\text { Malaria, } \\
\text { diarrhea }\end{array}$ & Infusion; Oral & \\
\hline & $\begin{array}{c}\text { Vernonia auriculifera } \\
\text { Hiern }\end{array}$ & Muthakwa & Shrub & $\mathrm{L}$ & $\begin{array}{l}\text { Malaria, loss of } \\
\text { appetite }\end{array}$ & Infusion; Oral & $\begin{array}{l}\text { Leaves used as } \\
\text { vegetables }\end{array}$ \\
\hline & $\begin{array}{l}\text { Vernonia lasiopus } \\
\text { O.Hoffm }\end{array}$ & Mwatha & Shrub & $\mathrm{L} / \mathrm{RB}$ & Malaria & Infusion; Oral & $\begin{array}{l}\text { Dry sticks used } \\
\text { for honey } \\
\text { harvesting }\end{array}$ \\
\hline Bignoniaceae & Kigelia Africana Lam. & Muratina & Tree & $\mathrm{L}$ & Malaria & $\begin{array}{c}\text { Hot water } \\
\text { decoction; Oral }\end{array}$ & $\begin{array}{c}\text { Making } \\
\text { traditional beer }\end{array}$ \\
\hline Caricaceae & Carica papaya $L$ & Mubabai & Tree & Seeds & Amoeba & Chewing; Oral & Fruits edible \\
\hline \multirow{2}{*}{ Cerastraceae } & $\begin{array}{l}\text { Catha edulis } \\
\text { (Vahl) Forssk. }\end{array}$ & Muraa & Shrub & $\mathrm{RB}$ & Stomachache & $\begin{array}{c}\text { Hot water } \\
\text { decoction; Oral }\end{array}$ & $\begin{array}{l}\text { Leaves used as } \\
\text { stimuli }\end{array}$ \\
\hline & $\begin{array}{l}\text { Maytenus undatus } \\
\text { (Thunb.)Blakelock }\end{array}$ & Muthithio & Shrub & $\mathrm{L} / \mathrm{RB}$ & $\begin{array}{l}\text { Malaria, } \\
\text { syphilis }\end{array}$ & $\begin{array}{c}\text { Hot water } \\
\text { decoction; Oral }\end{array}$ & Fruits edible \\
\hline Cucurbitaceae & Cucurbita maxima $L$. & Kirenge & Herb & $\mathrm{L}$ & $\begin{array}{c}\text { Fungal } \\
\text { infection, } \\
\text { healing of } \\
\text { umbrical cord }\end{array}$ & $\begin{array}{c}\text { Hot water } \\
\text { decoction, } \\
\text { infusion; Oral, } \\
\text { dermal }\end{array}$ & $\begin{array}{l}\text { Leaves and } \\
\text { fruits edible }\end{array}$ \\
\hline Euphobiaceae & $\begin{array}{l}\text { Neoboutonia } \\
\text { Neoboutonia }\end{array}$ & Mutuntuki & Tree & SB & Malaria & $\begin{array}{c}\text { Hot water } \\
\text { decoction; Oral }\end{array}$ & Building \\
\hline
\end{tabular}


Advances in Biotechnology \& Microbiology

\begin{tabular}{|c|c|c|c|c|c|c|c|}
\hline \multirow{2}{*}{ Building } & $\begin{array}{c}\text { Acacia mearnsii } \\
\text { De Wild. }\end{array}$ & Muthanduku & Tree & $\mathrm{L}$ & Measles & $\begin{array}{c}\text { Hot water } \\
\text { decoction; Dermal }\end{array}$ & $\begin{array}{l}\text { Building, ethno } \\
\text { veterinary }\end{array}$ \\
\hline & $\begin{array}{c}\text { Senna didymobortrya } \\
\text { Fres. }\end{array}$ & Murao & Shrub & $\mathrm{L} / \mathrm{RB}$ & $\begin{array}{c}\text { Malaria, } \\
\text { chicken pox }\end{array}$ & $\begin{array}{c}\text { Hot water } \\
\text { decoction; Oral, } \\
\text { dermal }\end{array}$ & $\begin{array}{c}\text { Ethno } \\
\text { veterinary }\end{array}$ \\
\hline \multirow{2}{*}{ Lamiaceae } & $\begin{array}{c}\text { Ajuga integrifolia Buch.- } \\
\text { Ham. }\end{array}$ & Kirurite & Herb & $\mathrm{W} / \mathrm{P}$ & Malaria & Infusion; Oral & \\
\hline & $\begin{array}{c}\text { Plectranthus barbatus } \\
\text { Andrews }\end{array}$ & Kijara & Shrub & $\mathrm{L}$ & Fresh wounds & $\begin{array}{c}\text { Crushing and } \\
\text { squeezing; Dermal }\end{array}$ & $\begin{array}{c}\text { Fencing, home } \\
\text { tissue }\end{array}$ \\
\hline Liliaceae & Aloe secundiflora Engel. & Cukurui & Shrub & $\mathrm{L}$ & $\begin{array}{l}\text { Malaria, } \\
\text { wounds }\end{array}$ & $\begin{array}{l}\text { Infusion; Oral, } \\
\text { dermal }\end{array}$ & Poultry \\
\hline Malvaceae & Malva verticillata $L$. & Muganjo & Herb & $\mathrm{RB}$ & Wounds & Grinding; Dermal & Ornamental \\
\hline Meliaceae & $\begin{array}{c}\text { Azadirachta indica } \\
\text { A. Juss }\end{array}$ & Mwarubainne & Tree & $\mathrm{L}$ & $\begin{array}{l}\text { Malaria } \\
\text { toothache, } \\
\text { stomach pain }\end{array}$ & $\begin{array}{c}\text { Hot water } \\
\text { decoction; Oral }\end{array}$ & \\
\hline Moringaceae & $\begin{array}{c}\text { Moringa oleifera } \\
\text { Lam. }\end{array}$ & Moringa & Tree & $\mathrm{L}$ & $\begin{array}{c}\text { Loss of } \\
\text { appetite, } \\
\text { diabetes, high } \\
\text { blood pressure }\end{array}$ & $\begin{array}{c}\text { Hot water } \\
\text { decoction; Oral }\end{array}$ & $\begin{array}{l}\text { Leaves used as } \\
\text { vegetables }\end{array}$ \\
\hline Oleaceae & Olea europaea L. & Mutero & Tree & SB & Malaria & $\begin{array}{c}\text { Hot water } \\
\text { decoction; Oral }\end{array}$ & For building \\
\hline Rosaceae & $\begin{array}{c}\text { Prunus Africana } \\
\text { Hook.f. }\end{array}$ & Mwiria & Tree & SB & Malaria & $\begin{array}{c}\text { Hot water } \\
\text { decoction; Oral }\end{array}$ & For building \\
\hline Rubiaceae & $\begin{array}{l}\text { Vangueria } \\
\text { madagascariensis } \\
\text { J.F. Gmel. }\end{array}$ & Mubiru & Tree & SB & Malaria & $\begin{array}{c}\text { Hot water } \\
\text { decoction; Oral }\end{array}$ & $\begin{array}{l}\text { Fencing, fruits } \\
\text { edible }\end{array}$ \\
\hline Rutaceae & Citrus limon (L) Burm. $f$. & Muriimo & Tree & Fruits & Common cold & Infusion; Oral & Fruits edible \\
\hline Solanaceae & $\begin{array}{c}\text { Solanum incanum } \\
\text { L. }\end{array}$ & Mutongu & Shrub & $\mathrm{RB}$ & $\begin{array}{l}\text { Stomachache, } \\
\text { malaria }\end{array}$ & $\begin{array}{c}\text { Hot water } \\
\text { decoction; Oral }\end{array}$ & \\
\hline Urticaceae & Urtica massaica L. & Kithaa & Herb & $\mathrm{L}$ & $\begin{array}{l}\text { Common cold, } \\
\text { menstrual } \\
\text { pains }\end{array}$ & $\begin{array}{c}\text { Hot water } \\
\text { decoction; Oral }\end{array}$ & $\begin{array}{l}\text { Leaves used as } \\
\text { vegetables }\end{array}$ \\
\hline Verbernaceae & Lantana camara $L$. & Kithiriti & Shrub & $\mathrm{L}$ & Common cold & $\begin{array}{c}\text { Hot water } \\
\text { decoction; Oral }\end{array}$ & $\begin{array}{l}\text { Fodder, fruits } \\
\quad \text { edible }\end{array}$ \\
\hline
\end{tabular}

(RB = Root Bark, SB = Stem Bark, W/p=Whole Plant, L=leaves $)$

Table 2: Diseases/Uses and percentage plant species usage

\begin{tabular}{|c|c|c|}
\hline Diseases Treated & Scores & $\%$ out of 28 Species \\
\hline Malaria & 14 & 50 \\
\hline Diarrhea & 2 & 7.1 \\
\hline Appetite loss & 1 & 3.6 \\
\hline Amoeba infection & 4 & 14.3 \\
\hline Syphilis & 2 & 7.1 \\
\hline Fungal infection & 1 & 3.6 \\
\hline Healing of umbilical cord & 1 & 3.6 \\
\hline Measles & 1 & 3.6 \\
\hline Chicken pox & 1 & 3.6 \\
\hline Toothache & 1 & 3.6 \\
\hline Stomach pain & 3 & 10.7 \\
\hline Diabetes & 1 & 3.6 \\
\hline High blood pressure & 1 & 3.6 \\
\hline Common cold & 3 & 10.7 \\
\hline Menstrual pain & 1 & 3.6 \\
\hline
\end{tabular}




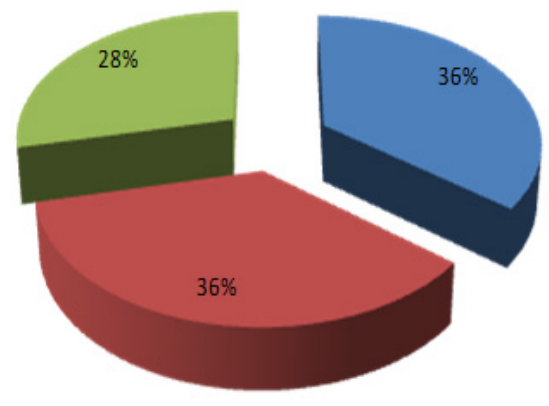

Figure 1: Percentage distribution of medicinal plants species according to the growth form.

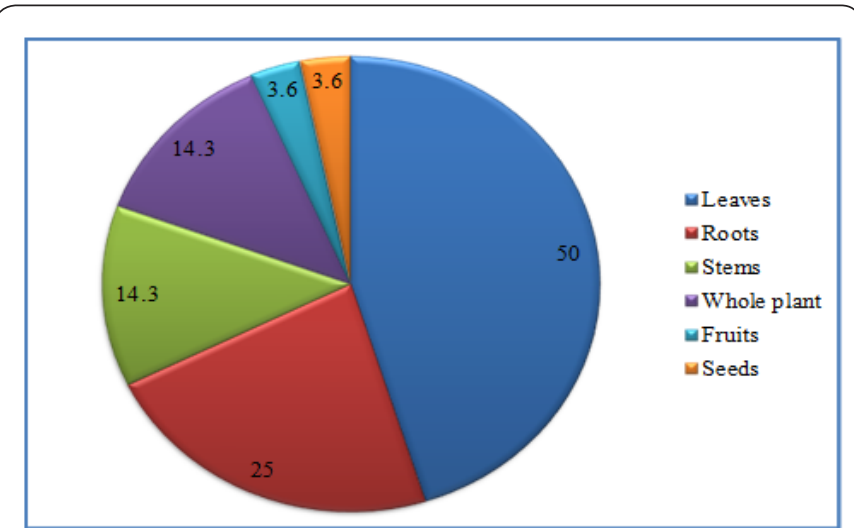

Figure 2: Percentage of medicinal plant parts used by traditional healers.

Trees and shrubs constituted the highest number of plant species recorded (10 species, 35.7\%) each (Figure 1). This demonstrates that they are the most commonly used plant habits in the study area. This could be linked to the high abundance of trees and shrubs in the area, making them easily accessible to the users [18]. Malaria and wounds were the commonly reported diseases (Table 2). Leaves were the most widely used plant part (14 species, $50 \%$ ) followed by roots ( 7 species, $25 \%$ ) (Figure 2). These results are in agreement with Chandrakumar et al. [19] who reported leaves as the most commonly used plant part of the reported medicinal plant uses. However the results of this study differ with other findings which recorded roots as the commonly used plant part for treatment [17,20,21]. The preference of harvesting leaves and root bark for ethno medicine is a threat to the continued existence of the target plants. Leaves and roots perform vital functions on plants and therefore their frequent and unsustainable harvesting can lead to the extinction of the species [22].

Majority of the remedies were prepared in the form of hot water decoction (17 species, 60.7\%), followed by infusion (8 species, 28.6\%), crushing and squeezing (2 species, $7.1 \%)$, Chewing ( 1 species, $3.6 \%$ ) and grinding ( 1 species. $3.6 \%$ ) (Figure 3 ). Most remedies were taken orally (21 species, 75\%) followed by dermal ( 4 species, $14.3 \%$ ) and both dermal and oral ( 3 species, $10.7 \%$ ) (Figure 4). These approaches of remedy preparation and administration were also reported in other studies $[17,20,23]$. There were no standardized dosage for the herbal remedies and most were administered through approximation (Table 3).

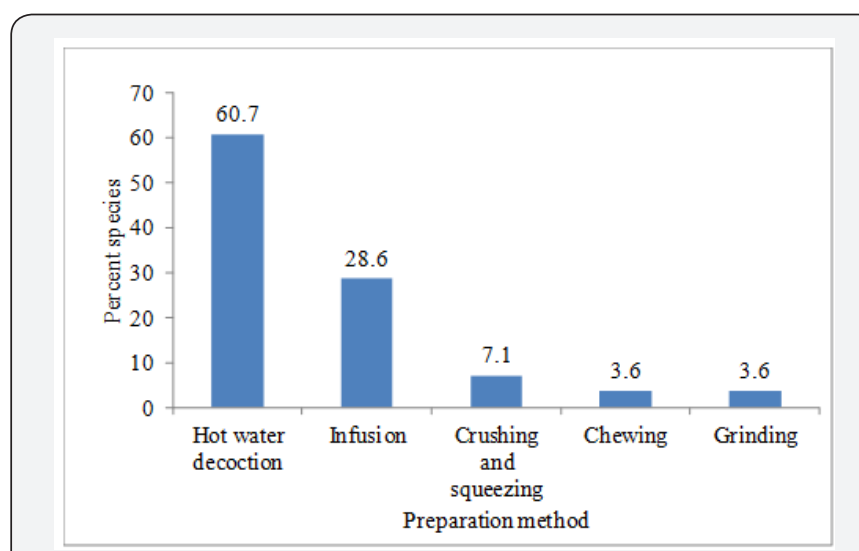

Figure 3: Methods of remedy preparation.

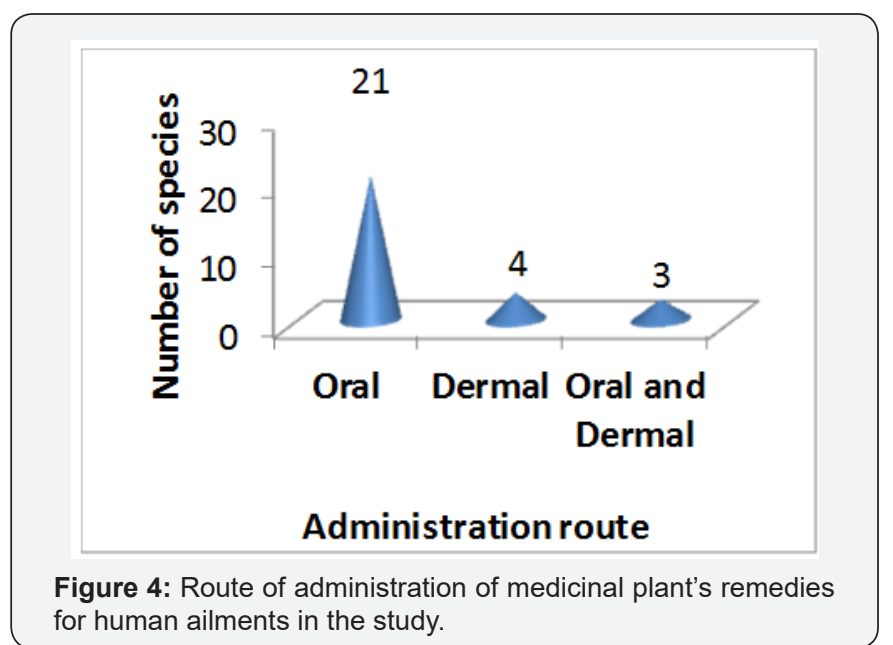

Table 3: Non-medicinal uses of the plants.

\begin{tabular}{|c|c|c|}
\hline Use & Number of Species & \% \\
\hline Food & 12 & 42.9 \\
\hline $\begin{array}{c}\text { Building \& } \\
\text { construction }\end{array}$ & 4 & 14.9 \\
\hline Ornaments & 1 & 3.6 \\
\hline Ethno-veterinary & 2 & 7.1 \\
\hline Fodder & 2 & 7.1 \\
\hline Traditional beer & 1 & 3.6 \\
\hline Others & 4 & 14.9 \\
\hline
\end{tabular}

\section{Conclusion and Recommendations}

The Kanjoo of the Ameru community have empirical knowledge about the use of medicinal plants, their ailments and 
diseases they are used to manage. This confirms the universal understanding that the traditional forms in health provision still dominates the lives of human for survival all over the world particularly in developing countries. There is, however, very scanty documentation of the medicinal flora of the area. There is an urgent need to document these plants and the indigenous knowledge for future references. The scientific validation of the plant species may help in discovering new drugs to tackle new reemerging and resistant pathogens. Not all the plants were covered in the study; more exhaustive documentation should be carried out to include them. It is also prudent that environmental education should be intensified for the harvesting techniques so that such plants whose roots are harvested for purposes of drugs are not exterminated but propagated in designated areas $[24,25]$.

\section{Acknowledgement}

Thanks to the people of Kanjoo and the Traditional Healers for providing the valuable information.

\section{References}

1. Patwardhan B, Warudhe D, Pushpangadan P, Bhatt N (2005) Ayurveda and traditional Chinese medicine: A comparative overview. Evid Based Complement Alternat Med 2(4): 465-473.

2. Shibata S (1981) Chinese Drug Constituents: Isolation of the biologically active Principles: in Advances in Natural Products Chemistry. Natori Kodasha S(Ed.), Tokyo, Japan, pp. 398-429.

3. Kokwaro JO (1976) A book of medicinal plants of East Africa. East Africa Literature Bureau, Nairobi, Kenya, pp. 68-168.

4. Kokwaro J O (1981) A review of research on plants for fertility regulation in Kenya. WHO symposium on plant derived products for fertility regulation. Seoul Korea, p. 8.

5. Kokwaro JO (1996) An Ethnobotanical study of East African medicinal plants and traditional medicine. Science Symposium. Baltimore Mary land, USA, pp. 23-24.

6. Ernest R (2005) The efficacy of herbal medicine. Fundamental and Clinical Pharmacology 19(4): 405-409.

7. Nariman F, Eftekhar F, Eabibi Z, Falsefi T (2004) Anti-Helicobacter pylori activities of Six Iranian Plants. Helicobacter 9(2): 146-151.

8. Nostro AM, Germano P, Angelo VD, Marino A, Cannatelli MA (2006) Extraction Methods and Bio autography for Evaluation of Medicinal Plant Antimicrobial activity. Letters in Applied Microbiology 30(5): 379-384.

9. Wang YC, Huang TL (2005) Anti-Helicobacter pylori activity of Plumbago zeylanica. FEMS Journal of Immunology and Medical Microbiology 43(3): 407-412.

10. Busia K (2005) Medical provision in Africa-past and present. Phototherapy Res 19(11): 919-923.

11. Gakuya DW, Itonga SM, Mbaria JM, Muthee JK, Musau JK (2013) Ethno botanical survey of bio pesticides and other medicinal plants traditionally used in Meru central district of Kenya. Journal of Ethno pharmacology 145(2): 547-553.

12. Gakuubi MM, Wanzala W (2012) A survey of plants and plant products traditionally used in livestock health management in Buuri district, Meru County, Kenya. Journal of Ethno biology and Ethno medicine 8: 39.

13. Agnew ADQ, Agnew S (1994) Upland Kenya Wild Flowers: A flora of the ferns and herbaceous flowering plants of upland Kenya. East Africa Natural History Society, Nairobi, Kenya, p. 115.

14. Beentje HJ (1994) Kenya Trees, Shrubs and Lianas. National museum of Kenya, Kenya.

15. Gitua JN, Muchiri DR, Nguyen XA (2012) In vivo anti malarial activity of Ajuga remota water extracts against Plasmodium berghei in mice. Southeast Asian Journal of Tropical Medicine and Public Health 43(3): 545-548.

16. Signorini MA, Piredda M, Bruschi P (2009) Plants and traditional knowledge: An ethnobotanical investigation on Monte Ortobene (Nuoro, Sardinia). Journal of Ethnobotany and Ethnomedicine 5: 5-6.

17. Lulekal KE, Bekele T, Yineger H (2008) An ethnobotanical study of medicinal plants in Mana Angetu District, Southeastern Ethiopia. Journal of Ethnobiology and Ethnomedicine 4: 10.

18. Lengkeek G (2003) Diversity makes a difference. Farmers managing inter and intra-specific tree species diversity in Meru, Kenya. The Netherlands PhD Thesis Wageningen University and Research Centre, Wageningen, Netherlands.

19. Chandrakumar P, Praveenkumar N Sushama N (2015) Ethno botanical studies on the medicinal plants of Darekasa Hill range of Gondia district, Maharashtra, India. International Journal of Research in Plant Science 5(1):10-16.

20. Kaingu CK, Mbaria J, Oduma JA, Kiama SG (2014) Ethno botanical study of medicinal plants traditionally used in Tana River County for management of illnesses. Asian Journal of Complementary and Alternative Medicine 2(2): 1-5.

21. Cheikhyoussef A, Shapi M, Matengu K, Asheke HM (2011) Ethno botanical study of indigenous knowledge on medicinal plant use by traditional healers in Oshikoto region, Namibia. Journal of Ethno biology and Ethno medicine 7:10.

22. Chinsembu KC, Hedimbi M (2010) An ethno botanical survey of plants used to manage HIV/AIDS opportunistic infections in Katima Mulilo, Caprivi region, Namibia. Journal of Ethno biology and Ethno medicine 6: 25.

23. Muthee JK, Gakuya DW, Mbaria JM, Kareru PG, Mulei CM, et al. (2011) Ethnobotanical study of anthelmintic and other medicinal plants traditionally used in Loitoktok district of Kenya. Ethnopharmacology 135(1): 15-21.

24. Wang HH, Manuzon M, Lehman M, Wan K, Luo H, et al. (2006) Food commensal microbes as a potentially important avenue in transmitting antibiotic resistance genes. FEMS Microbiology Letters 254(2): 226231.

25. Iwu MW, Duncan AR, Okunji CO (1999) New antimicrobials of plant origin: Perspectives on new crops and new uses. In: J Janick (Ed.), ASHS Press, Alexandria VA, USA, pp. 457-462. 


\section{Your next submission with Juniper Publishers will reach you the below assets}

- Quality Editorial service

- Swift Peer Review

- Reprints availability

- E-prints Service

- Manuscript Podcast for convenient understanding

- Global attainment for your research

- Manuscript accessibility in different formats

( Pdf, E-pub, Full Text, Audio)

- Unceasing customer service

Track the below URL for one-step submission https://juniperpublishers.com/online-submission.php 